\title{
A CORRELATION BETWEEN GROWTH AND RNA SYNTHESIS IN THE MOUSE OOCYTE
}

\author{
G. P. M. MOORE* AND SUE LINTERN-MOORE* \\ The Finsen Laboratory, The Finsen Institute, Copenhagen, Denmark
}

(Received 23rd Fanuary 1974)

The pattern of oocyte growth in relation to follicular growth is similar in the ovaries of many different mammalian species (Brambell, 1928, 1956; Mandl \& Zuckerman, 1952; Lintern-Moore, Peters, Moore \& Faber, 1974). There are two distinct and characteristic developmental phases. In the first phase, the oocyte and its follicle undergo coincident growth (Phase A). Oocyte growth then declines to zero, but follicular growth continues (Phase B), the final, preovulatory size being related to body weight (Brambell, 1956). In all of the species studied, e.g. bats, shrews, bank vole, mouse, rat, rabbit, ferret, Ericulus (the Madagascan hedgehog), pig, goat, spotted hyaena, rhesus monkey, baboon and man, oocyte size is positively and linearly correlated with follicle size during Phase A of growth (Brambell, 1956; Lintern-Moore et al., 1974). Similarly, oocyte nuclear size is positively and linearly correlated with oocyte size during both phases of growth in the mouse (Brambell, 1928), rat (Mandl \& Zuckerman, 1952) and man (Lintern-Moore et al., 1974) and oocyte nucleolar size is positively and linearly correlated with oocyte nuclear size during both phases of growth in the rat (Mandl \& Zuckerman, 1952) and mouse ( $y=$ $0 \cdot 10 \mathrm{x}+0.28 ; r=+0.65 ; P<0.001 ; n=430$, G. P. M. Moore and S. LinternMoore, unpublished observations). In all species studied, the oocyte reaches maximum size, i.e. at the completion of the first phase of growth, in follicles which contain many layers of granulosa cells but which show no antrum formation. With the exception of the pig (Brambell, 1956), this approximates to a mean oocyte diameter of $80 \mu \mathrm{m}$ and a follicle diameter of 100 to $200 \mu \mathrm{m}$.

It has recently been shown in the mouse that RNA synthesis (measured autoradiographically by uptake of $\left[{ }^{3} \mathrm{H}\right]$ uridine) is low in small, resting oocytes, but increases during growth and reaches a peak in oocytes of follicles which contain 100 to 200 granulosa cells (Moore, Lintern-Moore, Peters \& Faber, 1974). At this stage of follicular development, the oocyte has attained maximum size. Once oocyte growth has ceased, RNA synthesis rapidly declines (Oakberg, 1967, 1968; Moore et al., 1974). This also appears to be true for fully grown oocytes of rats and monkeys (Baker, Beaumont \& Franchi, 1969). The apparent relationship between oocyte growth and RNA synthesis in the mouse ovary has been investigated in the present study. Simple, linear correlations between oocyte nuclear and nucleolar sizes and $\left[{ }^{3} \mathrm{H}\right]$ uridine incorporation are demonstrated.

* Present address : Department of Zoology, Australian National University, Canberra, A.C.T. 2600, Australia. 


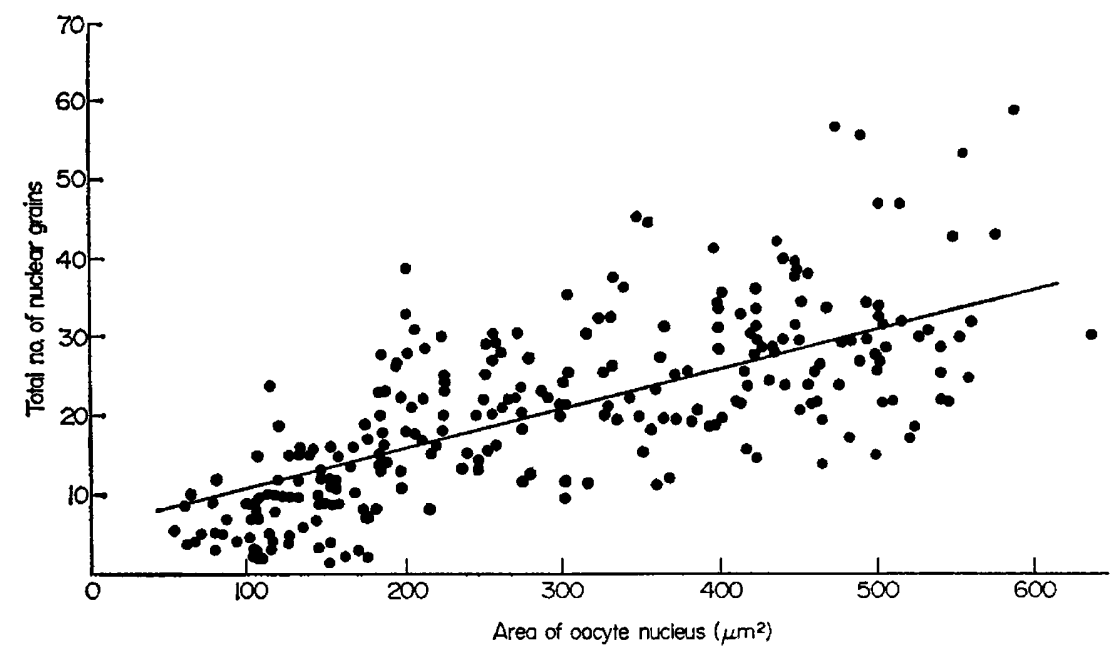

TExT-FIG. 1. Incorporation of $\left[{ }^{3} \mathrm{H}\right]$ uridine into the oocyte nucleus during Phase $A$ of growth. Total number of grains over the nucleus $(y)$ is positively and linearly correlated with oocyte nuclear area $(x): r=+0.70 ; P<0.001 ; y=0.05 x+5.91$. Data are pooled from readings made on four ovaries.

Twelve-week-old Bagg albino-strain mice received $100 \mu \mathrm{Ci}\left[5,6-{ }^{3} \mathrm{H}\right]$ uridine (43 Ci/mmol, Amersham) by intraperitoneal injection and were killed $1 \mathrm{hr}$ later. One ovary from each mouse was fixed in Bouin's solution, serially sectioned at $5 \mu \mathrm{m}$ and prepared for autoradiography with Ilford K2 liquid emulsion using standard procedures. Grain counts and area measurements were made on oocytes in which the plane of the section passed through the largest cross-section

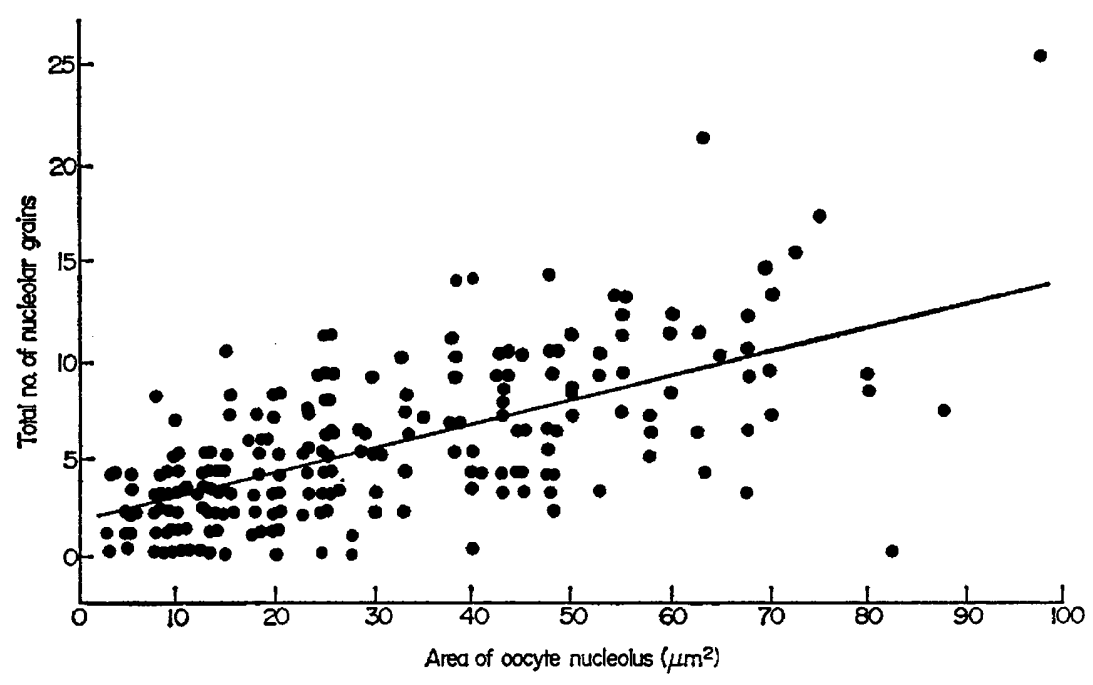

TEXT-FIG. 2. Incorporation of $\left[{ }^{3} \mathrm{H}\right]$ uridine into the oocyte nucleolus during Phase $\mathrm{A}$ of growth. Total number of grains over the nucleolus $(y)$ is positively and linearly correlated with oocyte nucleolar area $(\mathrm{x}): r=+0.65 ; P<0.001 ; \mathrm{y}=0.12 \mathrm{x}+1.63$. 
of the oocyte nucleus and nucleolus. Background grain numbers were determined from a volume of emulsion equivalent to that found over the oocyte nucleus. The background was subtracted from the total nuclear grain count (grains over the nucleolus and nucleoplasm) to give a nett grain count.

If the incorporation of $\left[{ }^{3} \mathrm{H}\right]$ uridine into the oocyte nucleus (expressed as number of grains) is compared with the size of the oocyte nucleus, a positive and linear correlation is found during Phase A of growth (Text-fig. 1). Incorporation of $\left[{ }^{3} \mathrm{H}\right]$ uridine into the oocyte nucleolus is also positively and linearly correlated with nucleolar size during Phase A of growth (Text-fig. 2). The relationship between uridine incorporation and oocyte nuclear and nucleolar sizes is not maintained during Phase B of follicle development as RNA synthesis rapidly declines (Moore et al., 1974).

The increase in RNA synthesis during growth of the mouse oocyte has a number of close parallels in other germinal and somatic cell systems. For example, in the marine echiuroid worm, Urechis caupo, RNA synthesis in the nucleus and nucleolus of the growing oocyte increases linearly during meiotic prophase (Das \& Alfert, 1966) and, in amphibian embryos, the rate of ribosomal RNA synthesis is positively correlated with nucleolar size (Brown, 1966). Similar relationships have also been found in cell cultures in vitro. During growth stimulation of mouse kidney epithelial cells and chick erythrocytes, changes in nuclear size are directly correlated with $\left[{ }^{3} \mathrm{H}\right]$ uridine incorporation and RNA polymerase activity (Auer \& Zetterberg, 1972; Auer, Moore, Ringertz \& Zetterberg, 1973; Carlsson, Moore \& Ringertz, 1973).

It is clear that the morphological and quantitative pattern of development of the oocyte and follicle during Phase A of growth in the mouse is very similar to that found in other mammalian species. On the basis of the data presented here, it seems reasonable to conclude that the pattern of oocyte RNA synthesis is also similar. Thus, it is proposed that, in the mammalian ovary, oocyte nuclear and nucleolar RNA synthesis increases linearly with oocyte size and reaches a peak in fully grown oocytes at the end of Phase A of growth.

This work was supported by The Danish Medical Research Council and Nordisk Insulinfond.

\section{REFERENCES}

Auer, G., Moore, G. P. M., Ringertz, N. R. \& Zetterberg, A. (1973) DNA-dependent RNA synthesis in nuclear chromatin of fixed cells. Expl Cell Res. 76, 229.

Auer, G. \& ZetTerberg, A. (1972) The role of nuclear proteins in RNA synthesis. Expl Cell Res. $75,245$.

Baker, T. G., Beaumont, H. M. \& Franchi, L. L. (1969) The uptake of tritiated uridine and phenylalanine by the ovaries of rats and monkeys. F. Cell Sci. 4, 655 .

Brambell, F. W. R. (1928) The development and morphology of the gonads of the mouse. Part III. The growth of the follicles. Proc. R. Soc. B, 103, 258.

Brambell, F. W. R. (1956) Ovarian changes. In Marshall's Physiology of Reproduction, Vol. 1, Part 1, pp. 455-459. Ed. A. S. Parkes, Longmans Green, London.

BRown, D. D. (1966) The nucleolus and synthesis of ribosomal RNA during oogenesis and embryogenesis of Xenopus laevis. Natn Cancer Inst. Monogr. 23, 297.

Carlsson, S.-A., Moore, G. P. M. \& Ringertz, N. R. (1973) Nucleocytoplasmic protein migration during the activation of chick erythrocyte nuclei in heterokaryons. Expl Cell Res. 76, 234.

DAs, N. K. \& Alfert, M. (1966) Nucleolar RNA synthesis during mitotic and meiotic prophase. Natn. Cancer Inst. Monogr. 23, 337. 
Lintern-Moore, S., Peters, H., Moore, G. P. M. \& Faber, M. (1974) Follicular development in the infant human ovary. $\mathcal{F}$. Reprod. Fert. 39, 53.

Mande, A. M. \& Zuckerman, S. (1952) The growth of the oocyte and follicle in the adult rat. $\mathcal{J}$. Endocr. 8, 126.

Moore, G. P. M., Lintern-Moore, S., Peters, H. \& FAber, M. (1974) RNA synthesis in the mouse oocyte. 7. Cell Biol. 60, 416.

Oakberg, E. F. (1967) ${ }^{3} \mathrm{H}$-uridine labelling of mouse oocytes. Archs Anat. microsc. Morph. exp. 56, Suppl. 3-4, 171 .

OAkBerg, E. F. (1968) Relationship between stage of follicular development and RNA synthesis in the mouse oocyte. Mutation Res. 6, 155. 